\title{
Aktivitas Penghambatan Polimerisasi Hem Ekstrak Etanol Daun Cambai Utan (Piper porphyrophyllum)
}

\author{
Arnida*, Nurlely, Nani Kartinah, Sutomo \\ Program Studi Farmasi, Fakultas MIPA, Universitas Lambung Mangkurat, Banjarmasin 70124 \\ *Email korespondensi: arnida01@ulm.ac.id
}

(Submit 15/03/2019, Revisi 05/09/2019, Diterima 20/12/2019)

\begin{abstract}
Abstrak
Resistensi Plasmodium terhadap obat malaria mengakibatkan kegagalan pengobatan. Oleh karena itu ketersediaan antimalaria baru sangat diperlukan untuk melawan resistensi. Pencarian obat baru terus dilakukan melalui berbagai cara termasuk eksplorasi tanaman yang berpotensi sebagai antimalaria. Penelitian ini bertujun untuk menentukan aktivitas penghambatan polimerissi hem dari ekstrak etanol daun Cambai Utan (Piper porphyrophyllum) berdasarkan nilai $I_{50}$. Pengujian aktivitas penghambatan polimerisasi hem merupakan suatu metode pengujian awal untuk mengetahui potensi antimalaria. Prinsipnya secara in vitro menyerupai mekanisme kerja antimalaria yang menghambat terjadinya polimerisasi hem di dalam Plasmodium. Sampel dan kontrol posistif (klorokuin) dibuat peirngakat konsnetrasi, direaksikan dengan hematin dan asam asetat glasial kemudian diukur absorbansinya pada Elisa Reader panjang gelombang $405 \mathrm{~nm}$, yang dipersamakan pada kurva baku. Nilai persen penghambatan versus konsentrasi dianalisis dengan analisis probit sehingga diperoleh nilai $\mathrm{IC}_{50}$. Persamaan kurva baku yang diperoleh yaitu : $y=0,011 x+0,247$. Penghambatan polimerisasi hem ekstrak etanol daun $P$. porphyrophyllum masing-masing konsentrasi 10; $5 ; 2,5 ; 1,25 ; 0,625 ;$ dan $0,3125 \mathrm{mg} / \mathrm{mL}$ adalah berturut-turut $91,82 \pm 5,47 \% ; 84,57 \pm$ $6,18 \% ; 77,28 \pm 7,81 \% ; 68,46 \pm 7,51 \% ; 57,24 \pm 6,23 \% ; 40,50 \pm 7,52 \%$. Nilai $I_{50}$ diperoleh menggunakan analisis probit. Analisis probit menunjukkan bahwa $\mathrm{IC}_{50}$ ratarata untuk ekstrak adalah $0,47 \pm 0,09 \mathrm{mg} / \mathrm{mL}$, sedangkan rata-rata $\mathrm{IC}_{50}$ dari klorokuin adalah $4,67 \pm 1,17 \mathrm{mg} / \mathrm{mL}$. Ekstrak etanol daun $P$. porphyrophyllum memiliki aktivitas penghambatan polimerisasi hem dengan nilai $\mathrm{IC}_{50} 0,47 \pm 0,09 \mathrm{mg} / \mathrm{mL}$.
\end{abstract}

Kata kunci: Cambai Utan, Piper porphyrophyllum, Heme Polimerization Inhibitory, Polimerisasi hem

\section{Outline}

- Pendahuluan

- Metode

- Hasil dan Pembahasan

- Kesimpulan

- Ucapan Terima Kasih

- Daftar Pustaka 


\section{Pendahuluan}

Penyebab gagalnya pemberantasan malaria adalah munculnya resistensi Plasmodium terhadap antimalaria dan resistensi vektor terhadap insektisida. Beberapa jenis nyamuk Anopheles (vektor) telah resisten terhadap insektisida seperti DDT sehingga mengakibatkan peningkatan jumlah kasus penyakit malaria di beberapa negara tropis ${ }^{1}$. Munculnya resistensi Plasmodium terhadap obat malaria mengakibatkan kegagalan pengobatan.

Pencarian obat baru terus dilakukan melalui berbagai cara termasuk eksplorasi dan pengembangan bahan alam serta sintesis obat untuk memperoleh obat yang efektif. Aktivitas antimalaria bahan alam dapat dibuktikan dengan beberapa pengujian, salah satunya adalah pengujian penghambatan polimerisasi hem. Penghambatan polimerisasi hem merupakan uji skrining awal ativitas antimalaria ${ }^{2}$. Daun Cambai Utan (Piper porphyrophyllum) dipilih berdasarkan kandungan metabolit sekunder yang mengandung alkaloid. Senyawa tumbuhan yang terbukti memiliki aktivitas penghambatan polimerisasi hem adalah senyawa fenolik seperti flavonoid, antrakuinon, tannin, saponin, terpenoid, golongan alkaloid ${ }^{3}$, dan glikosida ${ }^{4}$.

\section{Metode}

\section{A. Bahan}

Bahan yang digunakan dalam penelitian ini antara lain: daun $P$. porphyrophyllum, akuades, aluminium foil, amonia, asam asetat anhidrat, asam asetat glasial p.a., DMSO p.a., kain flanel, kertas saring, klorokuin difosfat p.a., kristal hematin p.a., Metanol, $\mathrm{NaOH}$, etanol 96\%. Daun P. porphyrophyllum diambil dari desa Guntung Manggis Kecamatan Landasan Ulin Kabupaten Banjarbaru Provinsi Kalimantan Selatan.

\section{B. Metode}

1. Ekstraksi

Pembuatan ekstrak dilakukan dengan metode maserasi yaitu perendaman sampel dengan pelarut etanol $96 \%$. Serbuk daun $P$. porphyrophyllum sebanyak $100 \mathrm{~g}$ dimasukkan dalam alat maserasi. Ekstraksi dilakukan selama 24 jam dan diremaserasi sebanyak 3 kali.

2. Preparasi Uji penghambatan polimerisasi hem

a) Pembuatan larutan $\mathrm{NaOH}$ 0,2 M dilakukan dengan menimbang $200 \mathrm{mg}$ kristal $\mathrm{NaOH}$, kemudian dilarutkan dengan akuades $10 \mathrm{~mL}$, kemudian digojok, dicukupkan volumenya sampai $25 \mathrm{~mL}$.

b) Pembuatan Larutan $\mathrm{NaOH}$ 0,1 M dilakukan dengan cara sebanyak $12,5 \mathrm{~mL}$ larutan $\mathrm{NaOH}$ 0,2 M dimasukkan ke dalam labu ukur ditambahkan akuades sampai $25 \mathrm{~mL}$.

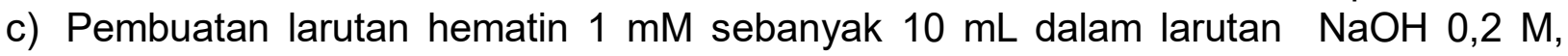
sebanyak $6,3349 \mathrm{mg}$ kristal hematin ditimbang saksama dan dilarutkan dengan $\mathrm{NaOH}$ 0,2 M sampai larutan mencapai $10 \mathrm{~mL}$.

d) Pembuatan kurva baku hematin, seri kadar larutan hematin dibuat dengan konsentrasi: 250,$125 ; 62,5 ; 31,25 ; 15,625 ; 7,8125$; dan 3,90625 $\mu \mathrm{M}$. Masingmasing konsentrasi sebanyak $100 \mu \mathrm{L}$ dimasukkan ke dalam sumuran microplate dan dilakukan pembacaan nilai absorbansi pada panjang gelombang $405 \mathrm{~nm}$ dengan ELISA Reader. 
e) Pembuatan larutan uji, sampel dibuat dengan konsentrasi $10 ; 5 ; 2,5 ; 1,25 ; 0,625$; $0,3125 \mathrm{mg} / \mathrm{mL}$. Kontrol positif yang digunakan adalah klorokuin dengan konsentrasi yang sam dengan sampel uji.

f) Uji aktivitas penghambatan polimerisasi hem ${ }^{4}$.

Bahan uji dengan berbagai tingkatan kadar ditambahkan sebanyak $50 \mu \mathrm{L}$, yaitu $10 ; 5$; 2,5; 1,25; 0,625; dan 0,3125 mg/mL. Replikasi sebanyak 3 kali untuk masing-masing kadar. Sebanyak $100 \mu \mathrm{L}$ larutan hematin $1 \mathrm{mM}$ dalam $\mathrm{NaOH} \mathrm{0,2} \mathrm{M} \mathrm{dimasukkan} \mathrm{ke}$ dalam mikrotube. Dalam memulai reaksi polimerisasi hem, ditambahkan $50 \mu \mathrm{L}$ larutan asam asetat glasial $100 \%(\mathrm{pH} \mathrm{2,6)}$ pada mikrotube yang sudah berisi larutan hematin dan sampel, kemudian diinkubasi pada suhu $37^{\circ} \mathrm{C}$ selama 24 jam. Sebagai kontrol positif adalah klorokuin dengan konsentrasi $10 ; 5 ; 2,5 ; 1,25 ; 0,625$; dan $0,3125 \mathrm{mg} / \mathrm{mL}$, sedangkan sebagai kontrol negatif adalah larutan DMSO $10 \%$ dan aquades. Setelah inkubasi berakhir, mikrotube disentrifuse dengan kecepatan 8000 rpm selama 10 menit. Supernatannya dibuang, endapan dicuci sebanyak 3 kali dengan $200 \mu \mathrm{L}$ DMSO 100\%. Masing-masing pencucian dengan cara disentrifuse berkecepatan $8000 \mathrm{rpm}$ selama 10 menit. Endapan yang diperoleh ditambah $200 \mu \mathrm{L} \mathrm{NaOH} \mathrm{0,1} \mathrm{M.} \mathrm{Setiap} 100 \mu \mathrm{L}$ larutan yang diperoleh dimasukkan ke dalam mikroplate 96 sumuran dan dibaca nilai absorbansinya dengan ELISA reader pada panjang gelombang $405 \mathrm{~nm}$. Nilai absorbansi yang diperoleh diplot ke persamaan garis regresi linear kurva standar sehingga dapat ditentukan konsentrasi $\beta$-hematin bahan uji pada setiap sumuran

\section{Hasil dan Pembahasan}

Hasil ekstraksi diperoleh bobot ekstrak 12,35 gram, dari 100 gram berat sampel, sehingga rendemennya sebesar $12,35 \%$. Konsentrasi larutan seri kadar hematin yang digunakan yaitu 250; 125; 62,5; 31,25; 15,625; 7,8125; dan 3,90625 $\mu \mathrm{M}$. Masingmasing konsentrasi tersebut diukur absorbansinya pada panjang gelombang $405 \mathrm{~nm}$ dan dibuat kurva hubungan antara absorbansi $(y)$ dengan konsentrasi $(x)$. Persamaan kurva baku yang diperoleh yaitu : $y=0,011 x+0,247$ dengan nilai koefisien korelasi $(r)$ yang dihasilkan adalah sebesar 0,997 dan nilai $r^{2}$ yang dihasilkan yaitu 0,994 (Gambar 5). Kadar $\beta$-hematin dari sampel uji maupun kontrol diperoleh dengan cara memasukkan harga absorbansi masing-masing bahan uji dan kontrol tersebut ke dalam persamaan kurva standar hematin yaitu: $y=0,011 x+0,247$ dengan $y$ adalah absorbansi dan $\mathrm{x}$ adalah kadar $\beta$-hematin. Nilai $\mathrm{IC}_{50}$ ini diperoleh menggunakan analisis probit. Analisis probit menunjukkan bahwa $\mathrm{IC}_{50}$ rata-rata untuk ekstrak adalah 0,47 \pm $0,09 \mathrm{mg} / \mathrm{mL}$. Sedangkan rata-rata $\mathrm{IC}_{50}$ dari klorokuin adalah 4,67 $\pm 1,17 \mathrm{mg} / \mathrm{mL}$ (Tabel 1 dan Lampiran 1). Klorokuin berfungsi sebagai kontrol positif, sedangkan DMSO 10\% berfungsi sebagai kontrol negatif untuk ekstrak. Selain itu, aquades berfungsi sebagai kontrol negatif dari klorokuin. Kontrol negatif tersebut berperan penting dalam penghitungan nilai persen penghambatan.

Uji penghambatan polimerisasi hem yang dilakukan pada ekstrak daun $P$. porphyrophyllum ini merupakan reaksi kimiawi yang meniru suasana pada sel hidup yaitu pada eritrosit yang terinfeksi Plasmodium. Pada suasana asam, hematin akan berpolimerisasi menjadi kristal $\beta$-hematin. Semakin banyak kristal $\beta$-hematin yang terbentuk, maka warna larutan (setelah kristal dilarutkan kembali dalam larutan natrium hidroksida 0,1 M) akan semakin pekat sehingga nilai absorbansi juga semakin besar. Dengan kata lain, senyawa uji yang mampu menghambat polimerisasi hematin ini akan 
Tabel 1. Pengaruh pemberian ekstrak etanol daun P. porphyrophyllum terhadap aktivitas penghambatan polimerisasi hem

\begin{tabular}{|c|c|c|c|c|}
\hline Bahan & Konsentrasi & \multirow{2}{*}{$\begin{array}{c}\text { Rerata Kadar } \\
\text { Hemozoin } \pm \text { SD }\end{array}$} & \multirow{2}{*}{ Rerata \% Penghambatan \pm SD } & $\mathrm{IC}_{50}$ \\
\hline \multirow{3}{*}{ Uji } & $(\mathrm{mg} / \mathrm{mL})$ & & & $(\mathrm{mg} / \mathrm{mL})$ \\
\hline & 10 & 15,97 & $91,82 \pm 5,47$ & \multirow{6}{*}{$\begin{array}{c}0,47 \pm \\
0,09\end{array}$} \\
\hline & 5 & 30,121 & $84,57 \pm 6,18$ & \\
\hline \multirow{4}{*}{ Ekstrak } & 2,5 & 44,364 & $77,28 \pm 7,81$ & \\
\hline & 1,25 & 61,576 & $68,46 \pm 7,51$ & \\
\hline & 0,625 & 83,485 & $57,24 \pm 6,23$ & \\
\hline & 0,3125 & 116,152 & $40,50 \pm 7,52$ & \\
\hline \multirow{6}{*}{ Klorokuin } & 10 & 61,32 & $58,57 \pm 4,04$ & \multirow{6}{*}{$\begin{array}{c}4,67 \pm \\
1,17\end{array}$} \\
\hline & 5 & 66,68 & $54,94 \pm 2,99$ & \\
\hline & 2,5 & 86,86 & $41,31 \pm 4,30$ & \\
\hline & 1,25 & 104,45 & $29,42 \pm 3,39$ & \\
\hline & 0,625 & 116,14 & $21,53 \pm 6,12$ & \\
\hline & 0,3125 & 124,36 & $15,97 \pm 7,56$ & \\
\hline
\end{tabular}

mengurangi kristal $\beta$-hematin yang terbentuk, sehingga semakin aktif senyawa uji, maka warna larutan akan semakin tidak berwarna serta nilai absorbansi akan semakin kecil ${ }^{3}$.

Hal tersebut terlihat pada uji penghambatan polimerisasi hem ekstrak etanol daun $P$. porphyrophyllum, pada mikroplate warna larutan semakin lemah dengan semakin bertambahnya konsentrasi. Maka dapat disimpulkan semakin bertambahnya konsentrasi ekstrak etanol daun $P$. porphyrophyllum, maka semakin bertambah besar aktivitas penghambatan polimerisasi hemnya. Hal lain, perlakuan yang dilakukan pada uji ini yaitu dilakukan pada suhu $37^{\circ} \mathrm{C}$ dan diinkubasi selama 24 jam karena pada suhu dan waktu tersebut, kristal $\beta$-hematin yang terbentuk adalah optimal ${ }^{5}$.

Aktivitas penghambatan polimerisasi hem dinyatakan dalam Inhibition Consentration $50 \%\left(\mathrm{IC}_{50}\right)$ yaitu kadar ekstrak yang mampu menghambat polimerisasi hem hingga $50 \%$. Suatu senyawa dapat dikatakan memiliki aktivitas penghambatan polimerisasi hem jika mempunyai nilai IC50 penghambatan polimerisasi hem lebih kecil dari nilai IC50 kloroquin sulfat, yaitu $37,5 \mathrm{mM}(12 \mathrm{mg} / \mathrm{mL})^{2}$. Berdasarkan kriteria tersebut di atas maka ekstrak etanol daun $P$. porphyrophyllum dapat dikatakan memiliki aktivitas penghambatan polimerisasi hem berdasarkan nilai IC50 yaitu 0,47 $\pm 0,09 \mathrm{mM}$.

\section{Kesimpulan}

Kesimpulan yang dapat diperoleh dari penelitian ini adalah ekstrak etanol daun $P$. porphyrophyllum memiliki aktivitas penghambatan polimerisasi hem dengan nilai $I_{50}$ sebesar 0,47 $\pm 0,09 \mathrm{mg} / \mathrm{mL}$. 


\section{Ucapan Terima Kasih}

Terima kasih kepada dekan Fakultas MIPA Universitas Lambung Mangkurat atas pendanaan melalui Program Dana DIPA; kepada Kepala Balai Veteriner Regional Kalimantan atas fasilitas Elisa Reader.

\section{Daftar Pustaka}

1. Willcox, M., Bodeker, G., Rasoanaivo, P., 2004, Traditional Medicinal Plants And Malaria, CRC Press, Boca Raton, 30, 260.

2. Baelsmans, R., E. Deharo, V. Munoz, M. Sauvain \& H. Ginsburg. 2000. Experimental Conditions for Testing the Inhibitory Activity of Chloroquine on the Formation of $ß$-Hematin, Experimental Parasitology. 42: 55-60.

3. Wahyono, Pudjono \& P. Widyati. 2010. Uji Aktivitas Senyawa Antiplasmodium dari Fungi Endofit Tanaman Artemsia annua L. Majalah Farmasi Indonesia. 21 : 230235.

4. Arnida. 2015. Isolasi dan Uji Aktivitas Antiplasmodium In Vitro Senyawa Aktif dari Umbi Hati Tanah (Angiopteris evecta). Disertasi, Program Pasca Sarjana Program Studi Ilmu Farmasi, Universitas Gajah Mada, Yogyakarta.

5. Basilico, N., E. Pagani, D. Monti, P. Olliaro, \& D. Taramelli. 1998. A Microtitre-based Method for Measuring The Haem Polymerization Inhibitory Activity (HPIA) of Antimalarial Drugs. Journal of Antimicrobial Chemotherapy. 42 : 55-60. 